\title{
Trophodynamics of the Fish Valenciennellus tripunctulatus. II. Selectivity, Grazing Rates and Resource Utilization
}

\author{
Ronald C. Baird and Thomas L. Hopkins \\ Department of Marine Science, University of South Florida, 830 First Street South, St. Petersburg, Florida 33701, USA
}

\begin{abstract}
Various patterns of resource utilization in the feeding strategy of Valenciennellus tripunctulatus, a small mesopelagic fish of tropical-subtropical oceans, were explored. Ivlev electivity indices suggest that copepods in general and the genus Pleuromamma in particular are being actively selected. Prey-size selection was apparent and strong negative indices were calculated for all plankton smaller than $1 \mathrm{~mm}$. Non-crustacean prey in all size classes also gave negative indices. Strong positive indices were indicated for prey size classes greater than $2 \mathrm{~mm}$. A model was developed to estimate grazing rates and efficiencies which is linearly influenced by swimming speed and plankton abundance, but exponentially affected by predator perception distances. Grazing efficiencies (i.e. prey ingested/prey encountered) for individual fish based on the model are relatively high $(>45 \%)$ for copepods in the $2-5 \mathrm{~mm}$ size classes. Daily grazing pressure by the $V$. tripunctulatus population on copepod resources was low ( $<9 \%$ ) for prey size classes $<3 \mathrm{~mm}$, but were as high as $43 \%$ for copepods in the 3-5 $\mathrm{mm}$ size range. Predation impact on members of the genus Pleuromamma, larger than $4 \mathrm{~mm}$, approached $100 \%$ in zones of highest predator density. The model suggests that $V$. tripunctulatus must have a sparse and nonaggregated distribution, and search considerable volumes of water each day to obtain its daily ration. While the impact of $V$. tripunctulatus alone on the prey resource field is not great, it apparently time-space shares common food resources with a broad array of zooplanktivorous predators in the mesopelagic environment.
\end{abstract}

\section{INTRODUCTION}

Theories of biological organization at the multispecies or 'community' level must ultimately be based on theories of evolutionary adaptation whereby species evolve along trajectories of increasing biological efficiency for a given set of environmental parameters. Feeding strategies can be envisioned as products of natural selection which also evolve in relation to biological efficiency. Economic models involving optimization of cost/benefit functions are increasingly being applied to feeding behavior (e.g. Schoener, 1971, and others). The relationship of predicted theoretical optima to conditions actually observed in natural populations is not well understood however. Evolutionary, physiological and mechanical constraints on populations are becoming apparent and these may impose limitations on the degree to which a given optimum applies.

In this paper, we continue our investigation of the feeding ecology of Valenciennellus tripunctulatus, a mesopelagic zooplanktivorous fish of oceanic gyre regions. We consider the ecological implications of various patterns of prey resource utilization, their relation to prey abundance, and the role of temporal-spatial relationships in predator-prey interactions. The following discussion is based primarily on evidence presented in the first paper of this series (Hopkins and Baird, 1981) in which the data base, sampling strategy and methods of analysis were treated in detail.

\section{PREY ABUNDANCE AND DIET COMPOSITION}

For the purpose of modelling predator-prey relationships, seven $162 \mu \mathrm{m}$ mesh plankton samples were chosen to describe prey density over the 300-350 m depth zone. These collections, three day and four night tows taken 7-12 June 1976 from Standard Station, were selected because they were completed in a relatively short time span, were of similar duration (73-96 min), 
were from the depth zone of maximum observed density for Valenciennellus tripunctulatus and coincided in time with at least one collection of fishes taken from the depth zone of interest.

It is assumed that zooplankton populations are relatively stable in low-latitude oligotrophic ecosystems and that plankton collections from June 1976 are representative of mean zooplankton abundances over time. Several recent studies support this assumption (see McGowan and Walker, 1979) and the relatively high degree of constancy in the diet of Valenciennellus tripunctulatus (Hopkins and Baird, 1981) taken from different years (and regions) infers stability in the composition of their food supply. In the following analyses we have included for comparison diet information from samples taken in the same time frame as the plankton tows as well as data from different years and seasons. Our conclusions are relatively insensitive to changes in prey density over the range of expected values and for first approximation are unlikely to be seriously in error.

The size distribution of zooplankton from the selected tows is presented in Table 1. Abundance in the $0.5-1 \mathrm{~mm}$ fraction has been underestimated because of escapement through the plankton net meshes. The remaining size classes considered, however, are probably represented with much less bias. The coefficients of variation are high indicating a degree of overdispersion in distribution. For the most abundantly represented size fractions the standard deviations are much less than the mean and the variances are similar to those determined by other investigators from zooplankton studies using horizontal net tows (e.g. Barnes, 1951; Hida and King, 1955; Cushing, 1962).

The size distribution of plankton is highly skewed, with the largest number of individuals being less than $2 \mathrm{~mm}$ in length. There is an order of magnitude decrease in density between the 1-2 mm and 2-3 mm size classes, while the rate of decrease is less marked for succeeding classes (i.e. items larger than $3 \mathrm{~mm}$ ). Regarding taxonomic composition, copepods represent greater than $89 \%$ of all zooplankton in the $0.5-3.0 \mathrm{~mm}$ size range in daytime collections (the time of active feeding) while they constitute but a small fraction of items larger than $4 \mathrm{~mm}$. During the day members of the copepod genus Pleuromamma, the most important diet item, made up between 26 and $61 \%$ of all copepods in each of the 1-4 mm plankton size classes. Diel changes in zooplankton abundance are also clearly reflected in the data. For copepods and the genus Pleuromamma there is a considerable decrease in abundance at night (Table 1) with night time densities often $50 \%$ or less than day. With but one exception (copepods $>5 \mathrm{~mm}$ ), the night time decrease in abundance occurred in all size categories.

Table 1. Abundance and size distribution of zooplankton between 300-350 m at Standard Station. Numbers in parenthesis are coefficients of variation (see Methods; in Hopkins and Baird, 1981); D: day; N: night

\begin{tabular}{|c|c|c|c|c|c|c|c|c|}
\hline \multirow{2}{*}{\multicolumn{2}{|c|}{ Category }} & \multirow[t]{2}{*}{ Period } & \multicolumn{6}{|c|}{ Plankton size classes ( $\mathrm{mm}$ ) } \\
\hline & & & $0.5-0.9$ & $1.0-1.9$ & $2.0-2.9$ & $3.0-3.9$ & $4.0-4.9$ & $5-10$ \\
\hline I & $\begin{array}{l}\text { Total zooplankton } \\
\left(\text { No. } 100 \mathrm{~m}^{-3}\right)\end{array}$ & $\begin{array}{ll}D & 3 \\
N & 3\end{array}$ & $\begin{array}{ll}3574 & (36 \%) \\
3049 & (27 \%)\end{array}$ & $\begin{array}{l}2700(25 \%) \\
1817(46 \%)\end{array}$ & $\begin{array}{ll}255 & (44 \%) \\
187 & (38 \%)\end{array}$ & $\begin{aligned} 103 & (24 \%) \\
88 & (95 \%)\end{aligned}$ & $\begin{array}{l}83(46 \%) \\
35(137 \%)\end{array}$ & $\begin{array}{ll}191 & (46 \%) \\
101 & (33 \%)\end{array}$ \\
\hline II & $\begin{array}{l}\text { Copepods } \\
\left(\text { No. } 100 \mathrm{~m}^{-3}\right)\end{array}$ & $\begin{array}{ll}\mathrm{D} \\
\mathrm{N} & 3\end{array}$ & $\begin{array}{ll}3192 & (69 \%) \\
2873 & (27 \%)\end{array}$ & $\begin{array}{l}2444(23 \%) \\
1623(49 \%)\end{array}$ & $\begin{array}{ll}199 & (62 \%) \\
117 & (17 \%)\end{array}$ & $\begin{array}{ll}70 & (20 \%) \\
30 & (33 \%)\end{array}$ & $\begin{aligned} 10 & (70 \%) \\
4 & (61 \%)\end{aligned}$ & $\begin{array}{l}1(100 \%) \\
3(47 \%)\end{array}$ \\
\hline III & $\begin{array}{l}\text { Pleuromamma spp. } \\
\left.\text { (No. } 100 \mathrm{~m}^{-3}\right)\end{array}$ & $\begin{array}{l}\mathrm{D} \\
\mathrm{N}\end{array}$ & $\begin{array}{r}50(174 \%) \\
1(192 \%)\end{array}$ & $\begin{array}{l}936(36 \%) \\
282(68 \%)\end{array}$ & $\begin{aligned} 121 & (69 \%) \\
54 & (54 \%)\end{aligned}$ & $\begin{aligned} 18(89 \%) \\
4(114 \%)\end{aligned}$ & $\begin{array}{l}1(170 \%) \\
-\end{array}$ & - \\
\hline IV & $\begin{array}{l}\text { Non-crustacean plankton } \\
\left.\text { (No. } 100 \mathrm{~m}^{-3}\right)\end{array}$ & $\begin{array}{l}D \\
N\end{array}$ & $\begin{aligned} 25 & (48 \%) \\
8 & (41 \%)\end{aligned}$ & $\begin{array}{l}90(72 \%) \\
80(56 \%)\end{array}$ & $\begin{array}{l}32(75 \%) \\
66(106 \%)\end{array}$ & $\begin{array}{r}9(39 \%) \\
52(154 \%)\end{array}$ & $\begin{array}{r}7(18 \%) \\
29(153 \%)\end{array}$ & $\begin{array}{ll}88 & (56 \%) \\
90 & (34 \%)\end{array}$ \\
\hline $\mathrm{v}$ & $\begin{array}{l}\text { Ratio of night to day } \\
\text { densities of: } \\
\text { Total zooplankton } \\
\text { Copepods } \\
\text { Pleuromamma spp. }\end{array}$ & $\begin{array}{l}N / D \\
N / D \\
N / D\end{array}$ & $\begin{array}{l}0.85 \\
0.90 \\
0.02\end{array}$ & $\begin{array}{l}0.67 \\
0.66 \\
0.30\end{array}$ & $\begin{array}{l}0.73 \\
0.59 \\
0.45\end{array}$ & $\begin{array}{l}0.85 \\
0.43 \\
0.22\end{array}$ & $\begin{array}{l}0.42 \\
0.40 \\
0.00\end{array}$ & $\begin{array}{l}0.72 \\
3.00 \\
-\end{array}$ \\
\hline & $\begin{array}{l}\text { Ratio }(\%) \text { of copepods to total } \\
\text { for plankton abundance }\end{array}$ & $\begin{array}{l}\mathrm{D} \\
\mathrm{N}\end{array}$ & $\begin{array}{l}89 \\
94\end{array}$ & $\begin{array}{l}91 \\
89\end{array}$ & $\begin{array}{l}78 \\
63\end{array}$ & $\begin{array}{l}68 \\
34\end{array}$ & $\begin{array}{l}12 \\
11\end{array}$ & $\begin{array}{r}<1 \\
3\end{array}$ \\
\hline VI & $\begin{array}{l}\text { Ratio }(\%) \text { of Pleuromamma } \\
\text { spp. to total copepods }\end{array}$ & $\begin{array}{l}\mathrm{D} \\
\mathrm{N}\end{array}$ & $\begin{array}{r}2 \\
<1\end{array}$ & $\begin{array}{l}38 \\
17\end{array}$ & $\begin{array}{l}61 \\
46\end{array}$ & $\begin{array}{l}26 \\
13\end{array}$ & $\begin{array}{r}10 \\
0\end{array}$ & $\begin{array}{l}0 \\
0\end{array}$ \\
\hline VII & $\begin{array}{l}\text { Ratio (\%) of non-crustacean } \\
\text { plankton to total zooplankton }\end{array}$ & $\begin{array}{l}\mathrm{D} \\
\mathrm{N}\end{array}$ & $\begin{array}{l}<1 \\
<1\end{array}$ & $\begin{array}{l}3 \\
4\end{array}$ & $\begin{array}{l}13 \\
35\end{array}$ & $\begin{array}{r}9 \\
59\end{array}$ & $\begin{array}{r}8 \\
83\end{array}$ & $\begin{array}{l}46 \\
89\end{array}$ \\
\hline
\end{tabular}




\section{PREY SELECTION}

Table 2 compares the size distribution of the major components of the diet of Valenciennellus tripunctulatus from three trawls taken from the $280-340 \mathrm{~m}$ depth zone. These collections were made in three different years and in different months and illustrate the basic similarity in diet size composition in the composite data set. The maximum number of prey in stomachs falls in a size range of 1 and $2.9 \mathrm{~mm}$, though peaks for the three tows vary. Our data on diet ontogeny indicates (Hopkins and Baird, 1981; their Fig. 5) the variability is related to the size of fish predominating in the catches. Hopkins and Baird (1981) discuss diet changes with ontogeny and an ontogenetic bias is present in the data from each tow. For example, sample C260 had the smallest fish ( $\bar{x}=$ $20.3 \mathrm{~mm}$ ) and the largest share of stomach items (65\%) in the $1-1.9 \mathrm{~mm}$ fraction whereas in sample M157 the fish were larger ( $\bar{x}=26.2 \mathrm{~mm}$ ) and the maximum (40\% of total prey) occurred in the next larger size class $(2-2.9 \mathrm{~mm})$.

The data for copepods show their dominance in all size classes particularly those exceeding $2 \mathrm{~mm}$. The percentages in the first two size classes $(0.5-0.9$, $1-1.9 \mathrm{~mm}$ ) are reduced somewhat by the presence of

Table 2. Valenciennellus tripunctulatus. Size distribution of prey in individuals from three trawls taken between $280-340 \mathrm{~m}$ at $27^{\circ} \mathrm{N} 86^{\circ} \mathrm{W}$ during the period of active feeding. B143: 30 fish $(\overline{\mathrm{x} S L}=24.2 \mathrm{~mm}), 6$ August $1972 ; \mathrm{M} 157: 12 \mathrm{fish}(\overline{\mathrm{x}} \mathrm{SL}=26.2 \mathrm{~mm}) 13$ August $1973 ; \mathrm{C} 260: 6$ fish $(\bar{x} S L=20.3 \mathrm{~mm}), 6$ June 1976. Percentage of total crustacean prey in each size class is in parentheses in I. $\bar{x}$ SL: mean standard length

\begin{tabular}{|c|c|c|c|c|c|}
\hline & \multicolumn{5}{|c|}{ Prey size classes (mm) } \\
\hline & $0.5-0.9$ & $1.0-1.9$ & $2.0-2.9$ & $3.0-3.9$ & $4.0-4.9$ \\
\hline \multicolumn{6}{|c|}{ I Number of crustacean prey } \\
\hline B 143 & $81(28)$ & $111(38)$ & $68(23)$ & $22(7)$ & $12(4)$ \\
\hline M157 & $4 \quad(9)$ & $11(24)$ & $18(40)$ & $6(13)$ & $6(13)$ \\
\hline C 260 & $4 \quad(4)$ & $58(65)$ & $17(19)$ & $9(10)$ & 1 (1) \\
\hline \multicolumn{6}{|c|}{ II $\%$ copepods in each size class } \\
\hline B 143 & 94 & 90 & 100 & 100 & 100 \\
\hline M157 & 50 & 91 & 100 & 100 & 100 \\
\hline C 260 & 75 & 93 & 100 & 100 & 100 \\
\hline \multicolumn{6}{|c|}{ III \% Pleuromamma spp. in each size class } \\
\hline B $143^{2}$ & 0 & 1 & 62 & 77 & 100 \\
\hline M157 & 0 & 0 & 67 & 67 & 83 \\
\hline C 260 & 0 & 12 & 53 & 67 & 100 \\
\hline
\end{tabular}

Table 3. Ivlev Electivity Indices, $E_{i}=r_{1}-p_{i} / r_{j}+p_{j}$, where $i=$ size class and $r_{i}$ and $p_{i}$ are relative abundances in diet and plankton, respectively, for various categories of prey. Plankton data from Table 1 and diet information from Table 2 . All data are from collections made between $280-350 \mathrm{~m}$

\begin{tabular}{|c|c|c|c|c|c|}
\hline & \multicolumn{5}{|c|}{ Prey size classes (mm) } \\
\hline & $0.5-0.9$ & $1.0-1.9$ & $2.0-2.9$ & $3.0-3.9$ & $4.0-4.9$ \\
\hline \multicolumn{6}{|c|}{$\begin{array}{l}\text { I Size selection of crustacean plankton }\left(\mathrm{E}_{\mathrm{i}} \text { based on percentages of total crustaceans found in stomachs that occur in each }\right. \\
\text { size class, i.e. values in parentheses in Table } 2 \text { ) }\end{array}$} \\
\hline B 143 & -.31 & -.03 & +.27 & +.56 & +.60 \\
\hline M157 & -.71 & 0 & +.53 & +.73 & +.80 \\
\hline C 260 & -.86 & -.36 & +.43 & +.67 & 0 \\
\hline \multicolumn{6}{|c|}{ II Copepods ( $E$, based on copepod percentage of each individual size class) } \\
\hline B 143 & +.03 & -.01 & +.12 & +.19 & +.79 \\
\hline M157 & -.28 & 0 & +.12 & +.19 & +.79 \\
\hline C 260 & -.09 & +.01 & +.12 & +.19 & +.79 \\
\hline \multicolumn{6}{|c|}{ III Pleuromamma spp. ( $E_{1}$ based on percentage this genus is of each size class) } \\
\hline B 143 & -1.00 & -.95 & +.01 & +.50 & +.82 \\
\hline M157 & -1.00 & -1.00 & +.05 & +.44 & +.78 \\
\hline C 260 & -1.00 & -.52 & -.07 & +.44 & +.82 \\
\hline \multicolumn{6}{|c|}{ IV Non-crustaceans (for fraction in each size class of plankton see Table 1) } \\
\hline B 143 & -1.00 & -1.00 & -1.00 & -1.00 & -1.00 \\
\hline M157 & -1.00 & -1.00 & -1.00 & -1.00 & -1.00 \\
\hline C 260 & -1.00 & -1.00 & -1.00 & -1.00 & -1.00 \\
\hline
\end{tabular}


small ostracods in the diet. Data on Pleuromammaspp. are included in Table 2 because of the importance of this genus as forage for Valenciennellus tripunctulatus. This genus in all three collections contributes relatively little to the two smallest size fractions, but becomes increasingly important with each successively larger size class in the $2-5 \mathrm{~mm}$ range. The diet information from these tows was combined with the plankton data in Table 1 to calculate Ivlev (1961) electivity indices for $V$, tripunctulatus diet as compared to plankton composition from the same depth zone. Of particular interest in this series is Tow C260 since it was taken over the same time period as the plankton collection.

The electivity indices show essentially the same pattern for all three collections. Regardless of the ontogenetic bias present, prey smaller than $1 \mathrm{~mm}$ are underutilized (Class I, Table 3). Prey from the $1.0-1.9 \mathrm{~mm}$ size class is taken in proportion to its abundance while prey larger than $2 \mathrm{~mm}$ (3-5 $\mathrm{mm}$ prey in particular) is positively selected. Copepods (II in Table 3) tend to be randomly taken at sizes less than $2 \mathrm{~mm}$ but become increasingly positively selected over other prey at sizes larger than $2 \mathrm{~mm}$. The trend for Pleuromamma spp. (III in Table 3) is similar to that for copepods in that there is negative selection in the smallest size classes, random choice in the $2.0-2.9 \mathrm{~mm}$ fraction and positive selection in the larger categories, 3.0-3.9, 4.0-4.9 mm. Indices for non-crustacean plankton (IV) exhibited maximum negative values for all size classes. Though non-crustacean forage is available in each of the size classes considered, it was rare items in the diet. Only three non-crustaceans (chaetognaths) were found among the 1917 prey items from the 363 fish examined.

In summary, the electivity data suggest that there is a strong size selection factor in prey choice in Valenciennellus tripunctulatus. The absence of available non-crustacean forage in the diet and the selection pattern for Pleuromamma spp. indicate that prey size is by no means the exclusive determinant and varying degrees of taxonomic selectivity are also operating in prey selection.

\section{GRAZING RATES AND EFFICIENCIES}

Useful first approximations of grazing rates and efficiencies for each size class of prey can be calculated from estimates of prey availability, predator density, diet composition and daily ration. To do this we have constructed a model using well-known mathematical formulations and several simplifying assumptions. For simplicity, calculations from the model are based on a representative individual of length $26 \mathrm{~mm}$, an approximate mean size of individuals caught by our trawls. The following assumptions were made: (a) prey-size distribution in the diet of the representative individual is approximated by the average calculated from fishes in the $24-29 \mathrm{~mm}$ size class (Table 4); (b) prey availability for the population is approximated by the zooplankton data presented in Table 1 ; (c) prey-size distributions (diet and plankton) are assumed constant and prey movement random; (d) each prey individual is assumed equally palatable; (e) perceptibility is a function of prey size; and (f) Valenciennellus tripunctulatus is presumed capable of efficient, sustained, low-velocity swimming but not adapted for prolonged high speed locomotion (see Marshall, 1971; Childress, 1977). Since diet consists almost exclusively of copepods (>95\%) only the copepod fraction of zooplankton density was considered in the analysis.

Little is known of actual swimming speeds in mesopelagic fishes. Recent studies of cruising and search speeds in various zooplanktivorous fishes indicate that both search and energetically optimal cruising speeds are proportional to body length (L) and that these are on the order of $1-2 \mathrm{~L} \mathrm{~s}^{-1}$ (e.g. Rosenthal and Hempel, 1970; Weihs, 1973; Ware, 1975). A speed of 1 body length (L) per second was chosen as a first approximation of search velocity $S_{v}$ (i.e. $S_{v}=2.6 \mathrm{~cm}$ $\left.\mathrm{s}^{-1}\right)$. Perception distance $\left(D_{\mathrm{p}}\right)$ is the mean or average range at which an individual prey item of a given size class can be detected. Visual discrimination in fishes has been shown to be a function of light intensity, the attenuation coefficient of light in water, inherent contrast of target and particularly the angle subtended by

Table 4. Valenciennellus tripunctulatus. Mean size distribution of prey in stomachs of individual fish of standard length 24-29 mm taken from trawls set during the period of active feeding $(1200-2200 \mathrm{~h})$ at Standard Station $\left(27^{\circ} \mathrm{N}, 86^{\circ} \mathrm{W}\right)$

\begin{tabular}{|c|c|c|c|c|}
\hline \multicolumn{5}{|c|}{ Prey size distribution ( $\mathrm{mm}$ ) } \\
\hline $0.5-0.9$ & $1.0-1.9$ & $2.0-2.9$ & $3.0-3.9$ & $4.0-4.9$ \\
\hline \multicolumn{5}{|c|}{ I $\%$ of total copepod number found in each size class } \\
\hline 6 & 39 & 28 & 20 & 7 \\
\hline \multicolumn{5}{|c|}{ II Ratio (\%) of density of Pleuromamma spp. to that of copepods for each size class } \\
\hline 0 & 7 & 33 & 40 & 88 \\
\hline
\end{tabular}


the prey (Tamura, 1957; Tamura and Wisby, 1963; Lythgoe, 1966; Hester, 1968). For predators foraging at depth under low light intensities, the visual field for maximum contrast should be located above the horizontal plane (Lythgoe, 1966; Baird et al., 1975). Perception also involves the recognition and integration of stimuli other than simply the visual characteristics of body shape of stationary prey (e.g. movement, bioluminescence, other sensory cues), the effect of which, in the photo-environment of interest, is difficult to evaluate. Observed perception distances in daylight for herring larvae feeding on small zooplankters are on the order of one body length (Rosenthal and Hempel, 1970) which was arbitrarily defined as the minimum perception distance (i.e. $D_{p} \min =2.6 \mathrm{~cm}$ ) for prey $<2 \mathrm{~mm}$ in length.

Ware (1978) estimated maximum sighting distances for feeding zooplanktivorous fishes to be roughly proportional to length $(\mathrm{L})$ raised to power 2.2. The perception distances assumed here for dimly lit waters are not likely to be substantially larger if only the visual properties of the prey are considered (e.g. other sensory cues or bioluminescence of prey could theoretically increase effective perception distances for certain prey taxa). Maximum perception distance, $D_{p} \max$, was therefore taken to be proportional to $\mathrm{L}^{2.2}$. Most of the prey eaten by Valenciennellus tripunctulatus were in the 1.0 to $5.0 \mathrm{~mm}$ size range and for the purpose of the model, minimum and maximum perception distances were set at the first $(1.0-1.9 \mathrm{~mm})$ and fourth $(4.0-4.9$ $\mathrm{mm}$ ) prey size classes listed in Table 5 . This has the effect of relating perception distance to prey size while setting limits based on observational fact and known physical properties of fish vision. $D_{p 1}$ for any prey size (i) between $D_{p}$ min and $D_{p}$ max was taken to be proportional to prey spherical cross sectional area $\left(A_{p}\right)$ as follows:

$$
D_{p l}=\frac{A_{p l}-A_{p l} \min }{A_{p} \max -A_{p} \min }\left(D_{p} \max -D_{p} \min \right)+D_{p} \min
$$

where: $A_{p 1}=\left(L_{p l} / 2\right)^{2} \pi$ and

$L_{p i}=$ mid-length of the ith prey size class.

The perception field for each size class i was taken to have the configuration of a semi-circle of radius $D_{p i}$ located vertically above the horizontal plane (i.e. prey not perceived below the horizontal). The assumption is based on the direction of incoming light (downwelling), position of eyes on the head (Hopkins and Baird, 1981; their Fig. 1) angle of maximum contrast (i.e. $90^{\circ}$ to the horizontal), and observations of feeding herring larvae (Rosenthal and Hempel, 1970)

Search volume $V_{s}$ can then be estimated for each prey size class $\mathrm{i}$ as follows:

$$
\mathrm{V}_{\mathrm{s} 1}=\frac{\pi\left(\mathrm{D}_{\mathrm{pi}}\right)^{2}}{2} \mathrm{~S}_{\mathrm{vi}} \mathrm{T}
$$

where: $\mathrm{T}=$ foraging time; $\mathrm{T}$ was taken to be $12 \mathrm{~h}$, a conservative estimate of length of time for potential feeding activity. $V_{s}$, then, is envisioned as having the geometric facies of a long convoluted tube.

Once $V_{s}$ is estimated then the mean number of copepod prey encountered $\left(N_{e}\right)$ by an average sized individual or contained in the search volume can be calculated from estimates (per $10^{2} \mathrm{~m}^{3}$ ) of prey density $\left(N_{p}\right)$ (see Parameter 1 , Table 5) for each size class $i$ as follows:

Table 5. Valenciennellus tripunctulatus. Summary of calculated grazing rates and efficiencies for an individual of $2.6 \mathrm{~cm}$ SL

\begin{tabular}{|c|c|c|c|c|}
\hline \multirow{2}{*}{ Parameters } & \multicolumn{4}{|c|}{ Prey size classes (mm) } \\
\hline & $1.0-1.9$ & $2.0-2.9$ & $3.0-3.9$ & $4.0-4.9$ \\
\hline 1 Copepods (no. $100 \mathrm{~m}^{-3}$ ) in plankton during day at $300-350 \mathrm{~m}$ & 2444 & 199 & 70 & 10 \\
\hline 2 Mean prey length $\left(L_{p 1}\right)$ & 1.50 & 2.50 & 3.50 & 4.50 \\
\hline 3 Mean prey cross section, $\operatorname{mm}^{2}\left(A_{p i}\right)$ & 1.77 & 4.91 & 9.62 & 15.90 \\
\hline 4 Perception distance, $\mathrm{cm}\left(\mathrm{D}_{\mathrm{pi}}\right)$ & 2.60 & 3.84 & 5.70 & 8.18 \\
\hline 5 Perception distance, $\mathrm{cm}$ at maximum grazing efficiency (at $\mathrm{E}_{01} \max =1$ ) & 1.30 & 3.87 & 5.70 & 6.06 \\
\hline 6 Search volume, $\mathrm{m}^{3}\left(\mathrm{~V}_{\mathrm{si}}\right)$ & 1.19 & 2.60 & 5.73 & 11.80 \\
\hline 7 Minimum search volume, $\mathrm{m}^{3}$ & 0.30 & 2.65 & 5.94 & 6.50 \\
\hline 8 Number of copepods encountered $\left(\mathrm{N}_{\mathrm{ei}}\right)$ & 29.08 & 5.17 & 4.01 & 1.18 \\
\hline $9 \mathrm{~N}_{\mathrm{ei}} \min$ & 29.08 & 2.37 & 0.83 & 0.12 \\
\hline $10 \mathrm{~N}_{\mathrm{ei}} \max$. & 288.00 & 23.48 & 8.26 & 1.18 \\
\hline 11 Minimum daily grazing rate $\left(G_{r i} \min \right)$ & 3.51 & 2.52 & 1.80 & 0.63 \\
\hline 12 Maximum daily grazing rate $\left(G_{\mathrm{ri}} \max \right)$ & 8.00 & 5.74 & 4.10 & 1.43 \\
\hline 13 Minimum daily grazing efficiency $\left(\mathrm{E}_{\mathrm{gi}} \mathrm{min}\right)$ & 0.12 & 0.49 & 0.45 & 0.53 \\
\hline 14 Maximum daily grazing efficiency $\left(\mathrm{E}_{\mathrm{g} 1} \mathrm{max}\right)$ & 0.28 & 1.11 & 1.02 & 1.21 \\
\hline 15 Maximum grazing efficiency at $N_{e i} \max$ & 0.03 & 0.24 & 0.50 & 1.21 \\
\hline
\end{tabular}
living at 300-350 $\mathrm{m}$ (see text for explanation). Prey $<1 \mathrm{~mm}$ not included 


$$
N_{e i}=\left(N_{p l}\right)\left(V_{s}\right) / 100
$$

Daily grazing rates $\left(G_{r}\right)$ were calculated by multiplying the minimum and maximum number of prey items in the daily ration of a $2.6 \mathrm{~cm}$ individual corrected for intestinal contents (i.e. 9 and 20.5 items, respectively) by the relative abundance of each prey size class (Table 2) in the composite population diet (ri). Thus, for size class $i$ :

$$
\mathrm{G}_{\mathrm{ri}} \min =9 \mathrm{ri} \text { and } \mathrm{G}_{\mathrm{ri}} \max =20.5 \mathrm{ri}
$$

Grazing efficiency, $\mathrm{E}_{\mathrm{g}}$, for any size class $\mathrm{i}$ was defined as:

$$
E_{g i}=G_{n} \min / N_{e i} \text { or } G_{r i} \max / N_{e i}
$$

$E_{g i}$, then, is an estimate of the ratio of number of prey eaten to number of prey encountered in the search volume for any size class $i$. The ratio is a measure of the efficiency with which the predator removes prey that fall within the presumed radius of perceptibility during a diel feeding cycle.

The results obtained from the model are summarized in Table 5 and must be interpreted with caution. The model is linearly affected by plankton abundance and relatively insensitive to errors of estimate within limits of expected values (see also coefficients of variation in Table 1). The model is also influenced linearly by search speed and given the narrow range of realistic swimming speeds, large scale errors are unlikely. Search volume and therefore frequency of predator- prey encounters is an exponential function of perception distance, and the model is sensitive to errors of estimate in perception distance.

To evaluate further the effects of perception distance several estimated distances were used in the calculations. The exponential effect on prey encountered by assuming maximum, $8.18 \mathrm{~cm}$, and minimum, $2.60 \mathrm{~cm}$, perception distances is presented in Table 5 by comparing prey encountered at $N_{\mathrm{ei}}$ min and $N_{\mathrm{ei}} \max$ (Parameters 9 and 10). Over all prey size classes, an order of magnitude more prey items (not biomass) would be encountered if all sizes of prey could be detected at the maximum perception distance. $\mathrm{N}_{e l}$ is considered a more realistic estimate, is consistent with available evidence (Parameter 8 ) and takes into account perception distances as a function of prey size. Grazing efficiencies, $G_{r i} \min$ and $G_{r i} \max$ (Parameters 11 and 12), were calculated using $N_{e i}$. Grazing efficiencies (Parameters 13 and 14) are lowest for the 1.0-1.9 $\mathrm{mm}$ prey size class and are much higher for $2-5 \mathrm{~mm}$ prey. Minimum daily grazing efficiencies in the latter are estimated between 45-53\%, while maximum daily grazing efficiencies exceed $100 \%$ (102-121\%). Once copepod prey are encountered Valenciennellus tripunctulatus presumably grazes very efficiently in the $2-5 \mathrm{~mm}$ size range even when perception distances are set at maximum (Parameter 15). It is apparent from Table 5 that $\mathrm{D}_{\mathrm{pi}}$ min is an unrealistic perception dis-

Table 6. Estimated daily production, no. $\left(10^{3} \mathrm{~m}^{3}\right)^{-1}$ for copepods and members of the genus Pleuromamma, as well as rates of

\begin{tabular}{|c|c|c|c|c|c|}
\hline \multirow{2}{*}{ Parameter } & \multicolumn{5}{|c|}{ Prey size classes (mm) } \\
\hline & $0.5-0.9$ & $1.0-1.9$ & $2.0-2.9$ & $3.0-3.9$ & $4.0-4.9$ \\
\hline \multicolumn{6}{|l|}{ I Daily production } \\
\hline Copepods & $1064^{\circ}$ & 815 & 66 & 23 & 3.3 \\
\hline Pleuromamma spp. & $17^{\circ}$ & 312 & 40 & 6 & 0.3 \\
\hline \multicolumn{6}{|l|}{ II Minimum no. removed } \\
\hline Copepods & 0.54 & 3.51 & 2.52 & 1.80 & 0.63 \\
\hline Pleuromamma spp. & 0 & 0.25 & 0.84 & 0.72 & 0.55 \\
\hline \multicolumn{6}{|l|}{ III Maximum no. removed } \\
\hline Copepods & 1.23 & 8.00 & 5.74 & 4.10 & 1.43 \\
\hline Pleuromamma spp. & 0 & 0.56 & 1.91 & 1.64 & 1.26 \\
\hline \multicolumn{6}{|c|}{ IV Minimum \% production removed } \\
\hline Copepods & 0.05 & 0.43 & 3.82 & 7.83 & 19.09 \\
\hline Pleuromamma spp. & 0 & 0.08 & 2.10 & 12.00 & 183.33 \\
\hline \multicolumn{6}{|c|}{$\mathrm{V}$ Maximum \% production removed } \\
\hline Copepods & 0.12 & 0.98 & 8.70 & 17.83 & 43.33 \\
\hline Pleuromamma spp. & 0 & 0.18 & 4.78 & 27.33 & 420.00 \\
\hline \multicolumn{6}{|c|}{$\begin{array}{l}\text { VI \% zooplankton in unutilized taxa } \\
\text { (i.e. \% non-copepods in plankton) }\end{array}$} \\
\hline & 1 & 3 & 13 & 9 & 8 \\
\hline
\end{tabular}
exploitation by Valenciennellus tripunctulatus at $300-350 \mathrm{~m}$. Zooplankton turnover rate $=30 \mathrm{~d}_{\mathrm{i}}$ predator density $=1 \mathrm{fish}$ $\left(10^{3} \mathrm{~m}^{3}\right)^{-1}$ 
tance. Grazing efficiencies in excess of $100 \%$ would be required at $\mathrm{D}_{\mathrm{pi}}$ min to obtain daily ration in the calorically important $2-5 \mathrm{~mm}$ prey size range (compare Parameter 9 to both 11 and 12). By setting grazing efficiency for each prey size class at $100 \%$, calculations based on the model predict that perception distances of 1.5 to $2.5 \mathrm{~L}$ are minimally required to obtain maximum ration $\left(\mathrm{G}_{\mathrm{r} 1} \mathrm{max}\right)$.

\section{PRODUCTION AND UTILIZATION}

To explore the potential effect of predation by $\mathrm{Val}$ enciennellus tripunctulatus on zooplankton production over the depth zone of maximum abundance (300-350 $\mathrm{m})$, the model was expanded to include an estimate of the percent daily production removed by grazing at minimum and maximum foraging rates. Predator density was assigned a value of 1 fish per $10^{3} \mathrm{~m}^{3}$, a value within the range of field observations (Hopkins and Baird, 1981). If it is assumed that the doubling or production rate of copepod prey is approximately $30 \mathrm{~d}$ (e.g. Deevey, 1960; Jeffries, 1962; Haq, 1965; Zillioux and Wilson, 1966; Katona and Moodie, 1969) then the mean daily production $\left(\mathrm{M}_{\mathrm{pl}}\right)$ of each prey size class $i$ per unit volume $\left(10^{3} \mathrm{~m}^{3}\right)$ can be calculated simply by dividing the observed prey density $N_{p 1}$ by $3\left(N_{p i}\right.$ expressed as numbers per $10^{2} \mathrm{~m}^{3}$ ). Daily utilization $\left(\mathrm{U}_{\mathrm{r}}\right)$ equals the grazing rate $\left(G_{r}\right)$ times predator density (PD) expressed per unit volume $\left(10^{3} \mathrm{~m}^{3}\right)$. Percent production removed $\left(\mathrm{PR}_{\mathrm{i}}\right)$, then, equals daily utilization rate divided by daily production of prey for any given size class $i$. The results of these calculations are summarized in Table 6 for a unit volume of water $\left(10^{3} \mathrm{~m}^{3}\right)$ at a depth where predator abundance is one per unit volume. The expressions are:

$$
\mathrm{M}_{\mathrm{p} 1}=\mathrm{N}_{\mathrm{p} 1} / 3 ; \mathrm{U}_{\mathrm{ri}}=\mathrm{G}_{\mathrm{r} 1} \times \mathrm{PD} ; \mathrm{PR}_{\mathrm{i}}=\mathrm{U}_{\mathrm{ri}} / \mathrm{M}_{\mathrm{pi}} \times 100
$$

As expected, the percentage of available copepod production utilized by Valenciennellus tripunctulatus increases with increasing prey size. Utilization of prey smaller than $1 \mathrm{~mm}$ is negligible and has even been overestimated because of underestimates of prey abundance from sampling bias. In the $1-3 \mathrm{~mm}$ range rates of removal remain under $8 \%$ for minimum grazing rate and less than $18 \%$ for the maximum. Large copepods in the $>4 \mathrm{~mm}$ class are more heavily impacted, however, with production utilization estimated higher than 19 and $43 \%$ for minimum and maximum grazing rates, respectively. A relatively small fraction $(<5 \%)$ of the production of Pleuromamma smaller than $3 \mathrm{~mm}$ appears to be utilized by $V$. tripunctulatus whereas impact becomes significant at sizes in excess of $3 \mathrm{~mm}$. The model indicates that grazing pressure on this genus is heaviest in the largest category, 4.0-4.9 mm, with calculated rates of utilization well in excess of $100 \%$. Pleuromamma xiphias, the only member of this genus to exceed $4 \mathrm{~mm}$ in length must receive considerable grazing pressure from $V$. tripunctulatus. It should be noted, however, that actual rates of prey production for a given taxon must be measured over the total vertical range of occurrence, and that local zones of high exploitation may not be indicative of grazing impact on production for the prey population as a whole. The vertical distribution of the two large species found at the sampling location, $P$. xiphias $(4.0-4.9 \mathrm{~mm}$ adult) and $P$. abdominalis (2.4-3.5 mm adult) migrate diurnally and have broad vertical ranges extending hundreds of meters at eastern Gulf locales and elsewhere (Hopkins, unpubl.; Roe, 1972). They would not be subject to high grazing rates by $V$. tripunctulatus over much of their vertical range.

\section{DISCUSSION}

The data and model results provide considerable insight into the nature of predator-prey relationships and trophic organization in oceanic environments. Considering prey choice, simple size selection exerts a dominant influence on prey selection in Valenciennellus tripunctulatus and may be characteristic of fish zooplanktivores (e.g. Brooks and Dodson, 1965; Detwyler and Houde, 1970). Various degrees of taxonomic selection are also important and the diet consists almost exclusively of copepods even though they are proportionately less abundant than non-crustacean taxa in the larger size classes.

Perhaps the most striking characteristic of tropicalsubtropical oceanic ecosystems as revealed in this study is the effect of space/time patterns of distribution on predator-prey relationships and the utilization of food resources. For Valenciennellus tripunctulatus, prey items are sparsely distributed, density varies diurnally and small size classes are several orders of magnitude more abundant than larger classes. The number of potential predator-prey encounters is limited, particularly with larger prey. This imposes severe constraints on potential rations obtainable by a zooplanktivorous predator. For instance, encounter rates during a 12 -h feeding bout at maximum ration are estimated at about $4 \mathrm{~h}^{-1}$ for copepod prey $1-5 \mathrm{~mm}$ in length, and $1-1.5 \mathrm{~h}^{-1}$ for preferred size classes $(>2 \mathrm{~mm})$. Grazing efficiencies should be correspondingly high and our model predicts very high grazing efficiencies for preferred items (50-100\%; Parameters 13 and 14; Table 5).

The data suggest that prey density does not greatly exceed the minimum required for Valenciennellus tripunctulatus to obtain the estimated daily ration. The 
effects of spatial differences in prey abundance can be stated in terms of supply/demand ratios in which supply, or density $D$ of prey at a given depth must be greater or equal to some $\mathrm{D}$ minimum if the predator is to obtain a given supply or ration R. In actuality, supply/demand relationships are complex and involve such factors as prey size distribution, predator growth rates, taxonomic composition of prey and a number of other energy related considerations. Nonetheless, it can be seen intuitively that as $D \rightarrow R$, selection should favor increased grazing efficiency while the competitive impact from predator-predator interactions should also increase. As $\mathrm{D} / \mathrm{R}$ ratios approach 1 , population density is increasingly determined by search volume, the degree of 'non-interference' between individual predators, and the mean turnover rate of the resource field. For the present case, the maximum daily search volume was estimated to be approximately $11 \mathrm{~m}^{3}$ and turnover rate was taken to be $30 \mathrm{~d}$. If $\mathrm{D} \approx \mathrm{R}$, then the minimum predator density supportable, assuming constancy of conditions, is equivalent to 3 average sized (26 mm) Valenciennellus tripunctulatus per $1000 \mathrm{~m}^{3}$. Competitors grazing the same resource field could theoretically impact predator population density by decreasing the mean $D$ and therefore realized $R$. The maximum observed density was about $1 \mathrm{~V}$. tripunctulatus $1000 \mathrm{~m}^{-3}$, with mean density for positive tows about half this value. The point here is that $V$. tripunctulatus must be sparsely distributed and non-aggregated as a result of the absolute abundance and spatial distribution of prey populations. It also follows that $V$. tripunctulatus must actively search considerable volumes of water daily to obtain $\mathrm{R}$ and search activity must require a significant portion of the daylight hours available.

Production in the zooplankton resource field appears relatively independent of effects of the particular predator population considered here. However, factors effecting abundance and spatial distribution of zooplankton resources as a whole could have marked effects on the array of predators which could exploit such resources. Predators such as Valenciennellus tripunctulatus are expected to be sensitive to subtle changes affecting the availability of zooplankton resources. Given the low encounter rates indicated, a reduction in photoperiod from 12 to $10 \mathrm{~h}$, for instance, restricts forage times by $1 / 6$ th, a potential reduction in ration of 1-4 items under constant conditions assumed here. Seasonality, ontogeny and vertical distribution all interact complexly to determine patterns and rates of prey utilization for a given predator. For instance, light and temperature which vary with depth can be expected to have marked effects on effective search volumes and metabolism. Depth related distribution patterns, in conjunction with behavioral and mor- phological specializations which reduce competition for sparse resources should be particularly well developed in gyre ecosystems.

Recent evidence from studies of biological sound scattering (Baird and Wilson, 1977; Farquhar, 1977) suggest that various oceanic regions have complex but characteristic vertical structures which can be related to distributions of sound-scattering organisms. Considerable data are now available that indicate mesopelagic fishes exhibit specific patterns (e.g. Backus et al., 1970; Badcock, 1970; Clarke, 1973, 1974; Hopkins and Baird, 1977; Pearcy et al., 1977) of vertical abundance which are non-randomly distributed and often vary diurnally. These patterns produce space/ time 'zones of exploitation' of zooplankton resources which vary with region, season and diel period. Space/ time zones of biological activity are characteristic of oceanic ecosystems and are a dominant theme in the patterns of prey utilization for Valenciennellus tripunctulatus.

\section{LITERATURE CITED}

Backus, R. H., Craddock, J. E., Haedrich, R. L., Shores, D. L. (1970). The distribution of mesopelagic fishes in the equatorial and western North Atlantic. J. mar. Res. 28: 179-201

Badcock, J. (1970). The vertical distribution of mesopelagic fishes collected on the Sond cruise. J. mar. biol. Ass. U. K. 71: 401-434

Baird, R. C., Hopkins, T. L., Wilson, D. F. (1975). Diet and feeding chronology of Diaphus taaningi (Mytophidae) in the Cariaco Trench. Copeia 1975, 356-365

Baird, R. C., Wilson, D. F. (1977). Sound scattering and oceanic midwater fishes. In: Anderson, N., Zahuranec, B. J. (eds) Proc. Int. Symp. Prediction of sound scattering in the ocean. Plenum Press, New York, pp. 549-563

Barnes, H. (1951). Horizontal plankton hauls. J. Cons. perm. int. Explor. Mer 17: 133--139

Brooks, J. L., Dodson, S. I. (1965). Predation, body size and composition of plankton. Science, N. Y. 150: 28-35

Childress, J. J. (1977). Physiological approaches to the biology of midwater organisms. In: Anderson, N., Zahuranec, B. J. (eds) Proc. Int. Symp. Prediction of sound scattering in the ocean. Plenum Press, New York, pp. 301-324

Clarke, T. A. (1973). Some aspects of the ecology of lanternfishes (Myctophidae) in the Pacific Ocean near Hawaii. Fish. Bull. U. S. 71: 401-434

Clarke, T. A. (1974). Some aspects of the ecology of stomiatoid fishes in the Pacific Ocean near Hawaii. Fish. Bull. U. S. 72: $337-351$

Cushing, D. H. (1962). Patchiness. Rapp. P.-v. Réun. Cons. perm. int. Explor Mer 153: 152-164

Deevey, G. B. (1960). The zooplankton of the surface waters of the Delaware Bay region. Bull. Bingham oceanogr. Coll. 17: $5-53$

Detwyler, R., Houde, E. D. (1970). Food selection by laboratory-reared larvae of the scaled sardine Harengula pensacolae (Pisces, Clupeidae) and the bay anchovy Anchoa mitchilli (Pisces, Engraulidae). Mar Biol. 7: 214-222

Farquhar, G. B. (1977). Biological sound scattering in the oceans. a review. In: Anderson, N., Zahuranec, B. J. (eds) 
Proc. Int. Symp. Prediction of sound scattering in the ocean. Plenum Press, New York, pp. 493-527

Haq, S. M. (1965). The larval development of Oithona nana. Proc. zool. Soc. Lond. 146: 555-566

Hester, F. J. (1968). Visual contrast thresholds of the goldfish (Carassius auratus). Vision Res. 8: 1315-1336

Hida, T S., King, J. E. (1955). Vertical distribution of zooplankton in the central equatorial Pacific, July-August 1952. Spec. scient. Rep. U. S. Fish Wildl. Serv. Fish. 144: $1-22$

Hopkins, T L., Baird, R. C. (1977). Aspects of the feeding ecology of oceanic mid-water fishes. In: Anderson, N., Zahuranec, B. J. (eds) Proc. Int. Symp. Prediction of sound scattering in the ocean. Plenum Press, New York, pp. $325-260$

Hopkins, T. L., Baird, R. C. (1981). Trophodynamics of the fish Valenciennellus tripunctulatus. I. Vertical distribution, diet and feeding chronology. Mar. Ecol. Prog. Ser. 4: 1-10

Ivlev, V. S. (1961). Experimental ecology of the feeding of fishes (transl. from Russ. by D. Scott), Yale University Press, New Haven

Jeffries, H. P. (1962). Succession of two Acartia species in estuaries. Limnol. Oceanogr. 7: 354-364

Katona, S. K., Moodie, G. F. (1969). Breeding of Psuedocalanus elongatus in the laboratory. J. mar. Biol. A.ss. U. K. 49: 743- 747

Lythgoe, J. M. (1966). Visual pigments and unterwater vision. In: Bainbridge, R., Evans, G. C., Rockham, O. (eds) Light as an ecological factor. British Ecol. Soc. Symp. No. 6. Blackwell, Oxford

Marshall, N. B. (1971). Explorations in the life of fishes, Harvard University Press, Cambridge

McGowan, J. A, Walker, P. W. (1979). Structure in the copepod community of the North Pacific Central Gyre. Ecol. Monogr. 49: 195-226

Pearcy, W. G., Krygier, E. E., Mesecar, R., Ramsey, F. (1977). Vertical distribution and migration of oceanic micronekton off Oregon. Deep Sea Res. 24: 223-245

Roe, H. S. J. (1972). The vertical distribution and diurnal migrations of calanoid copepods collected on the Sond cruise, 1965. III. Systematic account. Families Euchaetidae up to and including the Metridiidae. J. mar. Biol. Ass. U. K. 52: 525-552

Rosenthal, H., Hempel, G. (1970). Experimental studies of feeding and food requirements of herring larvae (Clupea harengus L.) In: Steele, J. H. (ed.) Marine food chains. University California Press, Berkeley, pp. 458-468

Schoener, T. W. (1971). Theory of feeding strategies. Ann. Rev. Ecol. \& Syst. 2: 369-404

Tamura, T. (1957). A study of visual perception in fish, especially on resolving power and accommodation. Bull. Jap. Soc. Fish. 22: 536-557

Tamura, T., Wisby, W. J. (1963). The visual sense of pelagic fishes especially the visual axis and accommodation. Bull. mar. Sci. Gulf Caribb. 13: 325-448

Ware, D. M. (1975). Growth, metabolism and optimal swimming speed of a pelagic fish. J. Fish. Res. Bd Can. 32 33-41

Ware, D. M. (1978). Bioenergetics of pelagic fish: Theoretical change in swimming speed and motion with body size. $\mathrm{J}$. Fish. Res Bd Can. 35: 220-228

Weihs, D. (1973). Optimal fish cruising speed. Nature, Lond. 245: 48-50

Zillioux, E. J., Wilson, D. F. (1966). Culture of a planktonic calanoid copepod through multiple generations. Science, N. Y. 151: 996-997 